\title{
The Need for Education to Pass in the Future Tense
}

\author{
Pece Trifunovski \\ South-West University "Neofit Rilski", Blagoevgrad, BULGARIA \\ Faculty of Philosophy, Department of Philosophical and Political Sciences
}

Received: 13 July 2020 - Accepted: 28 October 2020 - Published Online: 8 December 2020

\begin{abstract}
The problems in education are facing in a super-industrial society and a few resolutions on how it would improve in the future are just a couple of questions that attract my attention as a philosopher and as an educator. My main interest mostly concerns understanding the importance and the need for today's educational system to change to better prepare new generations for what tomorrow brings. For the basis of my thesis, my point of reference, as you might wish, I use the words of Alvin Toffler from the book Future Shock, in which he greatly focuses on education, in this piece of his, even though it was published fifty years ago, he deals with and indicates the problems in education, even back then unfortunately little has been done like today, a large part of the world is facing problems with the educational system and is in a desperate need of change, at least what is known till now, there are numerous problems.
\end{abstract}

Keywords: education, councils of the future, learning, relating, choosing.

\section{Introduction}

The problems in education is facing in a super-industrial society and a few resolutions on how it would improve in the future are just a couple of questions that attract my attention as a philosopher and as an educator. My main interest mostly concerns understanding the importance and the need for today's educational system to change to better prepare new generations for what tomorrow brings. For the basis of my thesis, my point of reference, as you might wish, I use the words of Alvin Toffler from the book Future Shock, in which he greatly focuses on education, in this piece of his, even though it was published fifty years ago, he deals with and indicates the problems in education, even back then unfortunately little has been done like today, a large part of the world is facing problems with the educational system and is in a desperate need of change, at least what is known till now, there are numerous problems.

Where do those problems in education come from, perhaps better than where they came from back then, and unfortunately many of them are still present today. Toffler will say: "Yet for all this rhetoric about the future, our schools are heading backward, towards a dying system, rather than forward to the emerging new society. Their vast energies are applied to cranking out Industrial Men - people tooled for survival in a system that will be dead before they are". ${ }^{1}$ Society

${ }^{1}$ Alvin Toffler, Future Shock, New York, Random House, 1970, p. 399.

(C) Authors. Terms and conditions of Creative Commons Attribution 4.0 International (CC BY 4.0) apply. Correspondence: Pece Trifunovski (PhD student), South-West University "Neofit Rilski", Faculty of Philosophy, Department of Philosophical and Political Sciences, Blagoevgrad, BULGARIA. E-mail: t.pece@yahoo.com. 
is rapidly changing everywhere, not just one system, it is likely that several systems will change during life to those we call children today.

And what should be done about it? Well: "To help avert future shock, we must create a super-industrial education system. In order to do this, we must search for our objectives and methods in the future, rather than in the past." 2 Not just for the super-industrial society, in general for all that follows, and what is real here and now, the education system must change everywhere in the world which would prepare young people for an overall rapid progress and high pace of development of society. Actually, almost everything, one branch of society, so crucially important - education has hardly changed at all. Of course, as usual, there are exceptions to the few examples, such as the Scandinavian countries that have made and are making serious efforts to change education systems. Perhaps the best example of this is Finland, where: "The most important thing is to know how to learn and adapt to a world full of change". 3

Why do we need changes in education? Because: "Mass education was the ingenious machine constructed by industrialism to produce the kind of adults it needed. The problem was inordinately complex. How to pre-adapt children for a new world - a world of repetitive indoor toil, smoke, noise, machines, crowded living conditions, collective discipline, a world in which time was to be regulated not by the cycle of sun and moon, but by the factory whistle and the clock. The inner life of the school thus became an anticipatory mirror, a perfect introduction to industrial society. The most criticized features of education today - the regimentation, lack of individualization, the rigid systems of seating, grouping, grading and marking, the authoritarian role of the teacher - are precisely those that made mass public education so effective an instrument of adaptation for its place and time". ${ }^{4}$ Here, personally and yet with hope that others share my thought is as Toffler says "education was a genius machine", but unfortunately not anymore, actually it is way too far from genius...well, it doesn't have to be a machine. Those, during that time, at the beginning of industrialization, we have to admit that they excellently solved their problem by unification, perhaps unifying education will be more eloquent. We can only be amazed and impressed by their work, we, fifty years after Toffler made the problem clear, we are still at the very beginning of a new education system which has to prepare children for the future. In a post-super-industrial society we would like to function by an industrial education system.

Measuring time during the industrial period, the kind of measuring time by the whistle in a factory, made education as it was: going to school in groups, with peers, everyone attending the same classes, same timing, the same duration for all those subjects, the beginning and the end were exactly known as was what was worked on and when. This was excellent for such a system where a large number of students later are introduced to the system with precise defined professions, starting with those mostly needed - factory workers, sophisticated accountants, bureaucrats, even teachers and doctors, with specified working hours.

Today, we cannot expect the same movement of things when time itself has changed. Factory workers are less needed, soon, they won't be needed at all, except for mechanical engineers, bureaucracy is slowly dying than expected but will surely disappear, doctors operate for 18 hours a day, the extent of knowledge teachers possess at the beginning of their career, and when this knowledge can be compared with the total extent of knowledge at the end of their career, most likely that would be a small percent, as for the methods of work ... that's just another story.

This isn't happening anymore, today, we wish to continue with the same style of education. Education is the most effective and efficient way to go forward towards a new system,

2 Ibid., p. 399.

3 https://www.fakulteti.mk/news/17-09-

o6/zoshto_sekoj_roditel_bi_sakal_negovoto dete da uchi_vo_finska.

4 Alvin Toffler, Future Shock, New York, Random House, 1970, p. 400. 
which we are getting to and will get to whether we believe so or not. With detailed changes in education, we can move on more securely and more successfully as a whole society.

\section{Online education}

Changes in education have to happen, they exist but are slow and they are not practical, we have to speed them up because: "Moreover, in the educational world of tomorrow, that relic of mass production, the centralized work place, will also become less important. Just as economic mass production required large numbers of workers to be assembled in factories, educational mass production required large numbers of students to be assembled in schools. This itself, with its demands for uniform discipline, regular hours, attendance checks and the like, was a standardizing force. Advanced technology will, in the future, make much of this unnecessary. A good deal of education will take place in the student's own room at home or in a dorm, at hours of his own choosing. With vast libraries of data available to him via computerized information retrieval systems, with his own tapes and video units, his own language laboratory and his own electronically equipped study carrel, he will be freed, for much of the time, of the restrictions and unpleasantness that dogged him in the lockstep classroom". 5 The centralized workplace still exists today, especially in factories where thousands of millions of people work, but soon, this won't be so, they too will soon be replaced by the products of the rapid development of technology. Rightly so Toffler says that uniformed discipline, regular lessons, presence checks, advanced technology, the future, will make this unnecessary. Yet, we cannot say that education is unnecessary, the process of going to school. School gives more than only knowledge; this is or should be clear to everyone. Toffler himself agrees with this.

The future is here, it has been here for quite some time through distance teaching and learning, actually known more popular and officially as online education, of which: "Online education is nothing new. Okay, the technology is relatively new. However, the concept is over 170 years old and has its origins in a correspondence course offered in Great Britain where the instructor sent lessons and received students' completed assignments by mail. Distance learning was born. The University of Illinois created an Intranet for its students in 1960. It was a system of linked computer terminals where students could access course materials as well as listen to recorded lectures in 1984 an Electronic University is created (EUN). Established with the mission of helping colleges and universities expand the availability of online courses, EUN offered its first online course in 1986 for use with DOS and Commodore 64 computers. In 1997, California Virtual University (CVU) was established as a clearinghouse to provide information about all online courses available from accredited California colleges and universities. MIT begins offering lectures and course materials online through its Open Course Ware project in 2002, most of which is provided free of charge to anyone in the world." "In 2009 around 5.5 million students worldwide passed at least one course through internet. In 2014 in USA 98\% of colleges and universities offer online programs" 7 . Not only college and university programs, students at a very young age can be educated this way. Programs for primary and secondary schools from around the world are available for the whole world. And if anyone doubted this would be possible to successfully achieve, today, May, 2020, with the new state we are in, with which I honestly hoped I wouldn't have the need to mention in this thesis, with which changes the world in almost every part, every segment of human society, perhaps mostly affected are schools, and for two months now, the world is operating through virtual classrooms and schools. Time will show whether this is good or not, the fact is that this is happening now. This new experience for many will change education forever.

5 Ibid., p. 275

${ }^{6}$ https://www.petersons.com/blog/the-history-of-online-education/.

7 Beth Dumbauld, https://www.straighterline.com/blog/brief-history-online-learning-infographic/. 
However, I am almost sure that Toffler wasn't thinking about this when he stated education will unfold in the student's room, this is currently so around the world. The availability of information and libraries will only increase as they do every day, are also available in that very room. As never before, education is available to everyone, but it depends on individual interest whether and how all that knowledge will be put to use.

That fundamental of learning in one's own room with all available information at hand, does not stop here, but as Toffler put it back then: "In the technological systems of tomorrow - fast, fluid and self-regulating - machines will deal with the flow of physical materials; men with the flow of information and insight. Machines will increasingly perform the routine tasks; men the intellectual and creative tasks. Machines and men both, instead of being concentrated in gigantic factories and factory cities, will be scattered across the globe, linked together by amazingly sensitive, near-instantaneous communications. Human work will move out of the factory and mass office into the community and the home". 8 This has happened, actually it is happening because machines are carrying out daily tasks whereas people carry out the intellectual and creative tasks. Perhaps going to work in a certain building or place will be present for a long time and is already modified, and in the future they will change even more. There isn't a big problem around this because we are all witnesses for "online" working, from the time technological systems enabled not recent but instant communication, physical remoteness did not represent and does not indicate a barrier of what so ever. Today, millions if not thousands of million people work 'online' and this number will only increase in the future. And how will we easily prepare for this through online education, of course.

However, we must not neglect the benefits of social skills that the child bears when going to school, but with good coordination between the two types of education, we would definitely gain an excellent combination for preparing youths for what tomorrow brings.

\section{Council of the Future}

This would be another of many possible ways to solve this multi-complex problem, which should be reviewed from many aspects to come to a long term solution and a great educational pattern for the generations of today and the future for their preparation for what is to follow. Toffler lays out the idea for "Counsellors to the future" as one of the possible solutions concerning this complex problem, as he puts it: "We must create a 'Council of the Future' in every school and community: Teams of men and women devoted to probing the future in the interests of the present. By projecting 'assumed futures,' by defining coherent educational responses to them, by opening these alternatives to active public debate, could have a powerful impact on education". 9 After reading his words for the first time, this idea seems perfect, but is it actually really like that and is it that easy to realize. Every school should have these counsellors, and the number of schools are huge. If these people work in schools, people who should consist of these counsellors, don't they then become a part of the school personnel. Questions, questions, questions... Who should actually make up these counsellors? According to Toffler: "Since no group holds a monopoly of insight into tomorrow, these councils must be democratic. Specialists are vitally needed in them. But Councils of the Future will not succeed if they are captured by professional educators, planners, or any unrepresentative elite. Thus students must be involved from the very start - and not merely as co-opted rubber stamps for adult notions. Young people must help lead, if not, in fact, initiate, these councils so that 'assumed futures' can be formulated

\footnotetext{
${ }^{8}$ Alvin Toffler, Future Shock, New York, Random House, 1970, p. 402.

${ }^{9}$ Ibid., p. 405 .
} 
and debated by those who will presumably invent and inhabit the future". ${ }^{10}$ Giving an opportunity to students, to those young people an important part is an advantage, because above all, children are more adaptable than adults, giving them the chance to be a part of these counsellors and to express their thoughts because after all the future is theirs. Surely today out of all times, more and more programs exist where students take up a great part of the teaching process not in this hierarchy structure of an industrial society, though it is important to give them greater freedom because of the recently listed characteristics that young people possess.

"As for curriculum, the Councils of the Future, instead of assuming that every subject taught today is taught for a reason, should begin from the reverse premise: nothing should be included in a required curriculum unless it can be strongly justified in terms of the future. If this means scrapping a substantial part of the formal curriculum, so be it."11 It is more than obvious that we are 50 years behind with the curriculum that was proposed by Toffler back then, but what frightens me is that there are no indications to change the curriculum, of course with a small number of exceptions from around the world. This is not enough, these changes are needed now and everywhere under the supervision of the "Counselors of the Future" or the ministries of education, or by whoever...as long as what cannot be strongly justified in terms of the future is removed.

To clarify things by Toffler and myself: "This is not intended as an 'anti-cultural' statement or a plea for total destruction of the past. Nor does it suggest that we can ignore such basics as reading, writing and math. What it does mean is that tens of millions of children today are forced by law to spend precious hours of their lives grinding away at material whose future utility is highly questionable. (Nobody even claims it has much present utility.) Should they spend as much time as they do learning French, or Spanish or German? Are the hours spent on English maximally useful? Should all children be required to study algebra? Might they not benefit more from studying probability? Logic? Computer programming? Philosophy? Aesthetics? Mass communications? Why not around stages of the human life cycle: a course on birth, childhood, adolescence, marriage, career, retirement, death. Or around contemporary social problems? Or around significant technologies of the past and future? Or around countless other imaginable alternatives ?"12 Enough! We are in desperate need of change because "There was a time when a man learned the language of his society and made use of it, with little change, throughout his lifetime. His "relationship" with each learned word or gesture was durable. Today, to an astonishing degree, it is not."13 Students should prepare for this kind of life, to learn to reason logically, evaluate ethically, to choose and so on. Computer lessons are almost present in every school program around the world. Enough of uniforming. Everyone is an individual. Yes, it is correct that he/she is part of a larger group - society, but society, nowadays is so diverse and fast that children, who, fortunately are easily adaptable by nature, have to learn to maintain and cultivate their characteristics to function successfully in the long run. They should be allowed to choose at a very young age what they wish to learn and how to learn. Yes, they sometimes will make mistakes but at least it won't be the same subject every year, they will learn from their mistakes to better deal with wrong choices which they will have made later in life, and will make.

Councilors of the future should be there because at the end: “...by making definite assumptions about the future and designing organizational and curricular objectives based on them, the Councils of the Future can begin to shape a truly super-industrial education system. One final critical step remains, however. For it is not enough to refocus the system on the future. We

\footnotetext{
${ }^{10}$ Ibid., p. 405.

${ }^{11}$ Ibid., p. 410.

12 Ibid., p. 410.

13 Ibid., p. 172.
} 
must shift the time-bias of the individual as well". ${ }^{14}$ Fortunately nowadays everyone has a different and a more appropriate approach for time than before even without "Councilors of the Future". Does this mean that such a body should not be created in the educational system? - Of course it is necessary and should be created even a day earlier. It is no longer a question of future shock, we have already, as I earlier mentioned, been through that phase. But in this new phase of "aftershock from the future" it doesn't only mean whether we will survive but the question is the quality of life, and not only of each individual but of the whole society, by introducing the new educational programs, methods, etc., by changing the overall picture of education, we would achieve this much faster and easier.

Another interesting and not so new method which Toffler in some way suggests for the achievements of the previously mentioned goals on the improvement of the educational process which can be reviewed by him from a recently suggested solution "learning from your own room" is "home education", the combination of the same with schools. As a justification of this proposal, he gives the following explanation: "As levels of education rise, more and more parents are intellectually equipped to assume some responsibilities now delegated to the schools. Near Santa Monica, California, where the RAND Corporation has its headquarters, in the research belt around Cambridge, Massachusetts, or in such science cities as Oak Ridge, Los Alamos or Huntsville, many parents are clearly more capable of teaching certain subjects to their children than are the teachers in the local schools. With the move toward knowledge-based industry and the increase of leisure, we can anticipate a small but significant tendency for highly educated parents to pull their children at least partway out of the public education system, offering them home instruction instead". ${ }^{15}$ Noone can deny the fact that some parents are more competent in knowledge than some teachers in some subjects and perhaps can better complete the task of tutoring or if you would rather prefer educating their children. If we take into account the fact that this kind of education is the oldest type of education when ancestors passed on the basic ways of survival to their descendants, later artisans, farmers, stockbreeders, almost everyone did the same, then schools appeared as a better way of education, does it make any sense to turn back instead of going ahead towards the inevitable - the future.

After the above elaborated paragraph, Toffler in his works gives a wider explanation on how that should look like and writes: "This trend will be sharply encouraged by improvements in computer-assisted education, electronic video recording, holography and other technical fields. Parents and students might sign short-term "learning contracts" with the nearby school, committing them to teach-learn certain courses or course modules. Students might continue going to school for social and athletic activities or for subjects they cannot learn on their own or under the tutelage of parents or family friends. Pressures in this direction will mount as the schools grow more anachronistic, and the courts will find themselves deluged with cases attacking the present obsolete compulsory attendance laws. We may witness, in short, a limited dialectical swing back toward education in the home." 16 Fifty years later, courts did not find themselves in these cases, maybe somewhere a secluded case exists, but far from that, it created or has created a great interest for this type of education. It is true that a great number of countries possess a legal opportunity for home education, but it is not so popular or has it a significant factor to increase and popularize. What happened in the past, is happening and most likely will happen in the future, few parents who feel and are competent (unfortunately sometimes parents feel competent but are far from being competent), and have the desire to do so, help their children quickly and easily better and progressively understand certain material, to solve sums or do a project. Though school is here

14 Ibid., p. 418.

15 Ibid., p. 406.

16 Ibid., p. 406. 
and that's how it is supposed to be, at least for the time being, and I don't think that that period is going to be short.

If you ask me, the school as an institute should exist even after the appearance of some new super-quick ways of understanding and mastering knowledge through rapid advancement: "Learning may be maximized through the use of controlled nutrition or drugs to raise IQ, to accelerate reading, or to enhance awareness. Such changes and the technologies underlying them will facilitate basic change in the organizational pattern." ${ }^{17}$ Nowadays we are getting far with these predictions and secular desires for rapid learning, many research institutions and companies (and certainly a genius in this own basement) are working on finding a way for instant learning. Some are already stating that they are close to inventing "thinking caps" ${ }^{18}$, and the ideas in many sciencefiction movies would become reality.

I honestly think that creating and introducing this type of technology wouldn't be something bad, if used properly of course (not to insert adds besides knowledge), as Toffler explained fifty years ago: "The rapid obsolescence of knowledge and the extension of life span make it clear that the skills learned in youth are unlikely to remain relevant by the time old age arrives. Super-industrial education must therefore make provision for life-long education on a plug-in / plug-out basis". ${ }^{19}$ Today, like never before, have we been witnesses for the reality of the above statement. Yet, tomorrow its reality will be greater. Education cannot suddenly stop only because we have grown up. Many countries for numerous professions have enacted a legal order to 'further educate' the professional. Like many other things, self-initiation here is crucial, fortunately more and more people are realizing the importance of keeping up with the latest developments from their field, even though they are aware that that mission is impossible. However, it is endeavored through seminars, courses to sustain education for adults so they can better integrate in society especially in the society of tomorrow.

But then: "If learning is to be stretched over a lifetime, there is reduced justification for forcing kids to attend school full time. For many young people, part-time schooling and parttime work at low-skill, paid and unpaid community service tasks will prove more satisfying and educational". ${ }^{20}$ We have to admit that what Toffler writes is logical, and I sincerely hope that when he means young people, he means those over 16 years of age which in most countries today is considered legal. But what until a person turns 16? Till then, do they have to go "part-time"? Perhaps community services for those from the age of ten to the age of fifty will cause greater satisfaction and will prove as educated. Yet, that would be in school tasks, so time spent in school would not decrease, maybe it would extend in certain cases, I do not see any harm in that. While those till ten years of age should go to school with a changed curriculum which will not destroy their creativity and would open their perspective to accept new novelties whereas education will better prepare them for their further life.

In the super-industrial, post-super industrial, society with all its technological development that it has reached and is reaching to every section of society in these new times, it's going to be like this for quite some time, education should not be taken from these novelties. Toffler with his book of introducing new technologies, the modified way of living in general, which will change the techniques and methods the way teachers teach will write: "Such innovations imply enormous changes in instructional techniques as well. Today lectures still dominate the classroom. This method symbolizes the old top-down, hierarchical structure of industry. While still useful for limited purposes, lectures must inevitably give way to a whole battery of teaching techniques,

${ }_{17}$ Ibid., p. 408.

18 https://www.bgr.in/news/now-electrical-thinking-caps-for-better-learning-302533/.

19 Alvin Toffler, Future Shock, New York, Random House, 1970, p. 407.

${ }^{20}$ Ibid., p. 407. 
ranging from role playing and gaming to computer-mediated seminars and the immersion of students in what we might call 'contrived experiences.' Experiential programming methods, drawn from recreation, entertainment and industry, developed by the psych-corps of tomorrow, will supplant the familiar, frequently brain-draining lecture". ${ }^{21}$ Unfortunately more often brainwashing lectures are still present today. The psyche-corps has not fulfilled its task here. This doesn't mean that it is taught only because its members didn't devote enough attention perhaps to the most important part of society. Or maybe it suits them, brain-washing, so that later in life people can use what they have accepted through education, for those - the members from the psycho-corps benefit well enough from the whole situation. However, thanks to the development of technology, there are changes in education which we cannot ignore, but they are not used enough to acquire the most out of it or get closer to it for students to better prepare for further life. Playing roles as a method in education is nothing new, actually it's one of the oldest if not the oldest method ever used. Most noticed in these changes from fifty years ago is the introduction of subjects that teach computer techniques and technology, or if you prefer IT subjects. The use of computers, with all that development has brought, in other subjects is the great change which has been introduced by education. But that often depends on desire, creativity, initiative and the knowledge of the teacher who uses technology.

\section{The three crucial areas}

What has to be done about methods and techniques in education, Toffler would write: "Schools of the future, if they wish to facilitate adaptation later in life, will have to experiment with far more varied arrangements. Classes with several teachers and a single student; classes with several teachers and a group of students; students organized into temporary task forces and project teams; students shifting from group work to individual or independent work and back all these and their permutations will need to be employed to give the student some advance taste of the experience he will face later on when he begins to move through the impermanent organizational geography of super-industrialism". ${ }^{22}$ No matter how nice the previous techniques for one students sound - one teacher or one student - many teachers, it should be clear to all of us that this technically cannot be possible to carry out, except for some isolated privileged cases. However, this aspect is totally justified from when it is a revolutionary novelty fifty years ago, but from the viewpoint of today, when the benefits are known for some of the viability above mentioned types of education, their weak use on a global level for me is nothing other than a disappointing truth. According to me, the Swiss education system went further ahead with the primary levels apart from having a teacher in class, a psychologist is present, and in some cases an assistant teacher. We can again see that very little has been done to change education and adapting to it in these new times, whereas challenges continue to grow because: "Unfortunately, this necessary diversification of data offerings will deepen the problems of over-choice in our lives. Any program of diversification must therefore be accompanied by strong efforts to create common reference points among people through a unifying system of skills. While all students should not study the same course, imbibe the same facts, or store the same sets of data, all students should be grounded in certain common skills needed for human communication and social integration". ${ }^{23}$ The diversification of offered information has already deepened the problems by the excessive choice in our lives, this will be so in the future if nothing is done, especially concerning the approach towards preparation of accepting and adapting to the rapid development of this diversification. Should not all students study the same course - it would be good if they didn't, as I previously stated, technically this is impossible (at least for now). I'll give an explanation on the

${ }^{21}$ Ibid., p. 408.

22 Ibid., p. 409.

23 Ibid., p. 413. 
facts later, what we definitely need is for all students to acquire certain skills for interpersonal communication and social integration. This, perhaps is something that has to be seriously worked on for changes in education which we will reach some improvement in accomplishing our final goal in education - preparing youths to easily accept the future.

We need changes because: "If we assume a continuing rise in transience, novelty and diversity, the nature of some of these behavioral skills becomes clear. A powerful case can be made, for example, that the people who must live in super-industrial societies will need new skills in three crucial areas: learning, relating and choosing". ${ }^{24}$ After having read once, someone might say that these skills are already acquired in todays' educational system, but if we closely take a look and process these skills, we'll see how much Toffler was right by putting these three areas that contribute in developing new and modern, skills for accepting a full-fledged living in a superindustrial society as key factors, that is, everything that follows in a foreseeable future.

As a term and experience "Learning" is well-known to everyone. Why is it that necessary to change this so old skill, what can be changed in it. Learning is learning. On this Toffler would write: "Learning. Given further acceleration, we can conclude that knowledge will grow increasingly perishable. Today's 'fact' becomes tomorrow's 'misinformation'." 25 I hope that you will agree that it is something we have all experienced at least once in our lives, we've felt it on our own skin. Such examples throughout history are numerous that the scope would be too large to use the information about them here, that's why I'll rely on your personal view and knowledge on the topic dear reader-thinker. And not as important as it happened in the past, what's important is how often it has happened today and how often will it happen tomorrow. Toffler rightly uses the term "perishable" to describe the state "knowledge" is in. The change that has to be made in the educational system, a novelty that needs to change it and improve competence in new generations, according to Toffler: "By instructing students how to learn, unlearn and relearn, a powerful new dimension can be added to education". ${ }^{26}$ I hope that you, like me, agree to this claim of his. For me, this state is so correct and true, especially great importance is given to the quote: "Psychologist Herbert Gerjuoy of the Human Resources Research Organization (writes Toffler) phrases it simply: "The new education must teach the individual how to classify and reclassify information, how to evaluate its veracity, how to change categories when necessary, how to move from the concrete to the abstract and back, how to look at problems from a new direction - how to teach himself. Tomorrow's illiterate will not be the man who can't read; he will be the man who has not learned how to learn'," 27 which Toffler uses in his book. After having considered such a deep opinion, I think it is needless to debate and consider the importance of "learning" in future educational programs. Mastering this skill will be crucial for future students, not that it isn't for todays' students, though very little can be done.

Toffler then writes about the next skill which needs special attention, and that is: "Relating. We can also anticipate increasing difficulty in making and maintaining rewarding human ties, if life pace continues its acceleration. Whether by more imaginative grouping of students, or by organizing new kinds of work-teams, or through variations of the techniques discussed above, education will have to teach us to relate". ${ }^{28}$ However Toffler mentions quite a lot about this topic in his book - chapter, it is good here to take a look at the importance of interpersonal relations in this new structure of society. New times have brought on a new way of life. About the many problems that Toffler talks about concerning connection, today we have

\footnotetext{
24 Ibid., p. 413.

25 Ibid., p. 414.

${ }^{26}$ Ibid., p. 414.

27 Ibid., p. 414.

${ }^{28}$ Ibid., p. 415-416.
} 
adapted them to the new conditions. Whether they are appropriately adapted, whether these new connections are socially acceptable is another question. Now "connections" between people are made easier than ever before. But today there is almost no "burden" to interpersonal relations. From this viewpoint we can only assume how that would seem tomorrow. We have to at least try and bring back a little "life" into the interpersonal relations. And not only to teach young people the right way of connection, adequate in a certain given situation during contact with another person. Of course, we cannot consider standardization of connection and relations, but establishing some form of normality between them - it would be a possible way to consider and learn in school, and boy do we need it. Even today, association and social ties are topics of study and elaboration in the education system, but if we look around us, we'll see that what is being done is not enough and a more serious approach is needed to consider and solve the problem.

The third is: "Choosing. If we also assume that the shift toward super-industrialism will multiply the kinds and complexities of decisions facing the individual, it becomes apparent that education must address the issue of over-choice directly". ${ }^{29}$ From the work in my thesis so far, which is based on Toffler's opinion, and many times confirmed from various factual sources, of which above in this chapter have been elaborated in more detail, is that technological development which was brought on by the new super-industrial society brought along more of everything. To know exactly what to choose from that "more of everything" is a real skill. This is where justification comes from for this skill of "choosing" as Toffler suggests, to be elaborated in educational systems and some previously determined social justified standards, to be taught in schools, thus helping young people easily step into their tomorrow for a better life, who will then contribute to a better life in society

Apart from these three, I'm sure that there would be other skills that the "Councilors of the Future" would suggest being elaborated and studied in the new improved and modified education systems. However, with the aim to remain closer to the topic that I'm dealing with, I'll stop here, at these three skills suggested by Toffler in his book Future Shock. Even though present, according to me - briefly presented and elaborated, I think that their importance and the necessity to be studied is more than obvious. To commence the change of education with one of these three would be very significant, because that beginning is already late and for a long time now and its every delay would only bring greater damage and problems for the society.

\section{Future of higher education}

Toffler devoted a separate part in his thesis for higher education, and of course, everyone who was a part of it in any way can understand the need and justification for it. For him, on higher education he would write: "The push for diversity, meanwhile, is igniting bitter conflict in education. Ever since the rise of industrialism, education in the West, and particularly in the United States, has been organized for the mass production of basically standardized educational packages. It is not accidental that at the precise moment when the consumer has begun to demand and obtain greater diversity, the same moment when new technology promises to make destandardization possible, a wave of revolt has begun to sweep the college campus. Though the connection is seldom noticed, events on the campus and events in the consumer market are intimately connected". $3^{\circ}$ I think that today, seldom someone who was a part of the campus did not notice the connection between the events on campus and at the consumer market. Well Facebook was created on campus for the campus and it conquered the whole world. The same was with Microsoft, its creation, Apple Inc., and many others of todays' most powerful and not so powerful companies were created there. The statement made about the wave of revolt that happened back

29 Ibid., p. 416.

30 Ibid., p. 272. 
then, I would consider as true and real taking into consideration that that statement was made for fifty or more years ago and comes from Toffler's word, who was totally aware of the events in society, in my opinion and that of many other competent individuals. The wave of revolt, today seems to have left the campus on this issue, that is why the offer is much bigger than before, not only is it easy to transfer from one university to another in many cases, it is encouraged by various programs available to the student.

Concerning the increase in variety of the offered courses for students, which then surely was very different to the ones they have today, Toffler would write: "While most colleges and universities have greatly broadened the variety of their course offerings, they are still wedded to complex standardizing systems based on degrees, majors and the like. These systems lay down basic tracks along which all students must progress. While educators are rapidly multiplying the number of alternative paths, the pace of diversification is by no means swift enough for the students. This explains why young people have set up 'para-universities' - experimental colleges and so-called free universities - in which each student is free to choose what he wishes from a mind-shattering smorgasbord of courses that range from guerrilla tactics and stock market techniques to Zen Buddhism and 'underground theater'." 31

Long before the year 2000, the entire antiquated structure of degrees, majors and credits will be a shambles. No two students will move along exactly the same educational track. For the students now pressuring higher education to destandardize, to move toward superindustrial diversity, will win their battle. The year 2000 is long behind us (twenty years ago) the whole structure of diplomas, specialties and credits is still here, so to say, far from antique. This perhaps is so because if it weren't for that entire system, it would become anarchic, and our modest experience up until now, as a society has shown us that we don't function well enough in an anarchy as an arrangement in any social branch. Students are still moving through those basic paths which they have to improve and make progress through, and not in twos but the number of students who are moving through those paths is big. Maybe he or she who is familiar with the credit transfer system will say that it is not like that and that higher studies are de-standardized, in comparison to those fifty years ago, but he or she who has experienced it knows that it is far from de-standard and the basics of one same specialty in students is almost identical everywhere around the world. Students who were putting pressure on higher education in order for it to be de-standardized, so that they could move towards super-industrial variety, we have to admit that they have lost the battle. I am not sure whether they lost the war because, as I mentioned earlier, there are changes in higher education and only time will show where they will get to.

\section{Conclusion}

Failure to diversify education within the system will simply lead to the growth of alternative educational opportunities outside the system. Thus we have today the suggestions of prominent educators and sociologists, including Kenneth B. Clark and Christopher Jencks, for the creation of new schools outside of, and competitive with, the official public school systems. Clark has called for regional and state schools, federal schools, schools run by colleges, trade unions, corporations and even military units. Such competing schools would, he contends, help create the diversity that education desperately needs. Simultaneously, in a less formal way, a variety of "paraschools" are already being established by hippie communes and other groups who find the mainstream educational system too homogeneous. ${ }^{32}$

\footnotetext{
${ }^{31}$ Ibid., p. 273.

$3^{2}$ Kenneth Clark, Alternatives to urban public schools, from A. Toffler (Ed.), The Schoolhouse in the City, New York, Praeger, 1968, p. 13.
} 
"The technology upon which these new freedoms will be based will inevitably spread through the schools in the years ahead - aggressively pushed, no doubt, by major corporations like IBM, RCA, and Xerox. Within thirty years, the educational systems of the United States and several Western European countries as well, will have broken decisively with the mass production pedagogy of the past, and will have advanced into an era of educational diversity based on the liberating power of the new machines.

In education, therefore, as in the production of material goods, the society is shifting irresistibly away from, rather than toward, standardization. It is not simply a matter of more varied automobiles, detergents and cigarettes. The social thrust toward diversity and increased individual choice affects our mental, as well as our material surroundings". 33

No matter the level of education we will notice changes in the education system after all that has been explained so far, after all that, all of us who are in some way interactive participants in any way in the educational process, are more than necessary because: "Finally, unless we capture control of the accelerative thrust - and there are few signs yet that we will tomorrow's individual will have to cope with even more hectic change than we do today. For education the lesson is clear: its prime objective must be to increase the individual's 'cope-ability' - the speed and economy with which he can adapt to continual change. And the faster the rate of change, the more attention must be devoted to discerning the pattern of future events." 34 Honestly, I doubt that someone will succeed to take control over the accelerated boom soon, what's left is to change the educational process because: "It is no longer sufficient for Johnny to understand the past. It is not even enough for him to understand the present, for the here-and-now environment will soon vanish. Johnny must learn to anticipate the directions and rate of change. He must, to put it technically, learn to make repeated, probabilistic, increasingly long-range assumptions about the future. And so must Johnny's teachers". ${ }^{35}$ Actually, better said, they should be the ones to teach him to adapt quickly and easily for what awaits him, his assumptions to teach him about the future to be as accurate as possible. Is this possible - I truly think it is, especially if that process of teaching and preparation begins as early as possible in Johnny's youth. And not only his teachers but his parents should visit some kind of basic course to prepare for the future to commence at an early age.

Indeed, adaptability of people, especially of children is huge in all aspects of their lives and so in this one by facing the great boom of the future. What's interesting is the fact that students, even in the educational system, either don't work at all or work very little which is devoted to the problem, but from everyday habits, they are more prepared to accept the future compared to any generation. My previous statement is based on a group of students from my home town Bitola, for more than five years now, every year around four hundred students answer similarly, to ultimately have the same sense of answer, which is that they are prepared to accept the rapid step that leads us towards the future not allowing themselves to reach that future shock. But should we stop here and do nothing after all this analysis and presentation. Of course we should and real soon, well organized everywhere around, globally. Only then will we be sure about a better tomorrow for the entire society. The boom has not yet brought such a huge shock but that doesn't mean that it won't in the future. And this one that we are experiencing and perhaps all of us who are living, the entire society would be well prepared and would even get way ahead if fifty years ago someone had accepted Toffler's measures, ways, advice and views. And they don't have to be the ones he said, accepting them didn't have to be of the same type, only one "Councilor of

33 Alvin Toffler, Future Shock, New York, Random House, 1970, p. 276.

34 Ibid., p. 403.

35 Ibid., p. 403. 
the Future", if there were anyone who would seriously show others how important it is for the future, we certainly would deal with it better than we are dealing with it as a whole society.

All that has been written, read, lived concerning education, one thing is sure: "Education must shift into the future tense" 36

\section{Acknowledgements}

This research did not receive any specific grant from funding agencies in the public commercial, or not-for-profit sectors.

The author declares no competing interests.

\section{References}

Clark, K. (1968). Alternatives to urban public schools. In A. Toffler (Ed.), The schoolhouse in the city. New York: Praeger.

Dumbauld, B. (2014). A brief history of online learning. www.straighterline.com

IANS (2014). Now, electrical "thinking caps" for better learning. www.bgr.in.

Toffler, A. (1970). Future shock. New York: Random House.

TOM (2017). The history of online education. www.petersons.com

Grozdanovski, T. (2017). Why would any parent want their child to study in Finland? [Гроздановски,Т. Зошто секој родител би сакал неговото дете да учи во Финска?]. www.fakulteti.mk.

${ }^{36}$ Ibid., p. 427. 
P. Trifunovski - The Need for Education to Pass in the Future Tense

C O A $\mathbf{s}$ 